\title{
(Game-Based) Student Response Systems Engage Students with Research-Teaching Nexus Activities and Support Their Skills Development
}

\author{
Maria Limniou' ${ }^{1}$, Rosie Mansfield ${ }^{2}$ \\ ${ }^{1}$ School of Psychology, University of Liverpool, Liverpool, UK \\ ${ }^{2}$ Manchester Institute of Education, University of Manchester, Manchester, UK \\ Email: Maria.Limniou@liverpool.ac.uk, rosie.mansfield@postgrad.manchester.ac.uk
}

How to cite this paper: Limniou, M., \& Mansfield, R. (2019). (Game-Based) Student Response Systems Engage Students with Research-Teaching Nexus Activities and Support Their Skills Development. Creative Education, 10, 36-47.

https://doi.org/10.4236/ce.2019.101003

Received: October 8, 2018

Accepted: January 7, 2019

Published: January 10, 2019

Copyright ( 2019 by author(s) and Scientific Research Publishing Inc. This work is licensed under the Creative Commons Attribution International License (CC BY 4.0).

http://creativecommons.org/licenses/by/4.0/

cc) (i) Open Access

\begin{abstract}
Research-teaching nexus framework assists teachers to support activities which are focused on the current research in the disciplines promoting discussions and skills development. The challenges for teachers are related to student research skills development, knowledge application across contexts and student experience on statistics. The aim of this investigation was to compare student views following two approaches: one which integrated technology and one which did not into the teaching delivery process. Forty first-year Psychology students were split into two groups (A and B) and followed both teaching approaches in a different attending order (one approach without the use of technology and another one with technology or vice versa). (Game-based) student response systems (PollEveryWhere and Kahoot) were integrated into the teaching process, whilst the learning content was the same for both cases. Students evaluated the two approaches by completing two online surveys with items relating to research-teaching nexus activities and skills development. The integration of (game-based) student response systems into teaching process increased student engagement in learning, improved the interactions between students and teachers and allowed them to develop the relevant research skills. Students received the technology intervention as a way to work on a creative learning environment which allowed them to develop skills and knowledge/experience around research methods and statistics. Although this investigation took place in a Psychology School, the design of a research methods and statistics module based on the combination of collaborative problem-based learning with the use of (game-based) student response systems can be applied in other disciplines.
\end{abstract}




\section{Keywords}

Research-Teaching Nexus, (Game-Based) Student Response Systems, Student Engagement, Skills Development, Creative Learning Environment

\section{Introduction}

The research-teaching nexus framework assumes that teaching and research can be integrated into a Higher Education curriculum. The emphasis of this framework is placed on activities and skills developed by students and on teaching delivery (Healey, Jordan, Pell, \& Short, 2010). The four descriptions of this framework include (Griffiths, 2004; Healey, 2005):

- Research-led (RL) learning and teaching is informed by current and ongoing research in the discipline and specialist research interests of school staff.

- Research-tutored (RT) learning and teaching promotes research discussions with a focus on students and staff critically discussing research in the discipline.

- Research-oriented (RO) learning and teaching emphasizes the process by which research findings are produced, focusing on developing students' knowledge of research methodologies, skills and techniques specific to their discipline or future profession.

- Research-based (RB) learning and teaching is undertaking research and inquiry focusing on ensuring that the student learns in research and/or inquiry mode.

Universities usually follow at least one of the above research-teaching approaches to support their research activities and to support students to develop their skills (Robertson \& Blackler, 2006; Levy \& Pertulis, 2012). All disciplines include at least a relevant module on research methods and statistics allowing students to understand the principles of research methods and obtain the relevant skills (Mackeski, Buhrmann, \& Lowrey, 2008; Aditomo, Goodyear, Bliuc, \& Ellis, 2011; Gardner \& Willey, 2018). Many researchers have advocated that the above four research-teaching nexus descriptions provide students the opportunity to understand the topic of research methods and statistics and to build up their own capabilities of research area (Healey \& Jenkins, 2009; Stappenbelt, 2013; Walkington, 2015). However, others have identified some factors that might influence the adoption of any of research-teaching nexus activities to Higher Education, such as the relationship between teachers and students, students' involvement in teaching process, teachers' availability to support and engage students with learning and research process and students' awareness with the actual research that takes place around them (Buckley, 2011; Hajdarpasic, Brew, \& Popenici, 2015; Al-Maktoumi, Al-Ismaily, \& Kacimov, 2016).

Additionally, the abstract nature of research methods and statistics can be challenging for students, and further effort is required by teachers to enhance 
student skills and to apply knowledge across contexts, retaining knowledge over a long period of time (Ramirez, Schau, \& Emmioglu, 2012; Boyle et al., 2014). Tishkovskaya and Lancaster (2012) reviewed the challenges of statistical education and provided an overview of suggested strategies and techniques for developing research-based statistics courses. For example, a collaborative problem-solving approach could promote statistical reasoning, interactive activities with feedback and the use of real-world examples. Despite the difference in problem-based activities, class size and evaluation, research suggested that a problem-based approach can improve students' motivation and engagement (Ball \& Pelco, 2006; Elder, 2015) and produced higher statistics scores (Karpiak, 2011). Although Wiggins, Chiriac, Abbad, Pauli and Worrell (2016) believed that a problem-based approach could blend theoretical and applied topics, and teach students to apply knowledge across contexts and to real world problems, some other researchers suggested that the success of this approach is dependent on the students' prior knowledge (Kirschner, Sweller, \& Clark, 2006). However, all the above researchers studied how they could enhance the teaching approach for a module relevant to research methods and statistics based on collaborative problem-based learning but they did not study the influence of technology on students' views in relation to the research-teaching nexus approaches and skills development.

The aim of this investigation was to compare student views following two approaches one which integrated technology and one which did not, into the teaching delivery process for a first-year research methods and statistics module. Specifically, a teaching approach based on collaborative problem-based learning was designed and evaluated against another one in which technology was integrated into the learning process. The appropriate use of technology could theoretically enhance the student learning process, but the choice of technology tools should align with learning outcomes, activities and environment (Roblyer, 2016). For example, in order to support learning through interactions with content in a collaborative problem-based face-to-face learning environment, the choice of the Web 2.0 applications and real time quizzes might allow students to be engaged in their learning process (Rice, 2012; Stowell, 2014).

Kahoot and PollEveryWhere are online (game-based) student response systems which allow students to answer questions in real-time, obtain statistics based on whole class responses and assess their level of understanding (Firsing, Yannessa, McGough, Delport, Po, \& Brown, 2017; Plump \& LaRosa, 2017). However, there are some differences between the two online systems. Kahoot (https://www.kahoot.it) is a game-based student response system which allows students to compete against one another while testing their knowledge by answering the multiple-choice questions as quickly as possible (Wang, 2015). PollEveryWhere (https://www.polleverywhere.com) is a student response system which allows students to respond to different types of questions, such as multiple choice, open-ended, clickable image, rank order and word cloud questions (Shon 
\& Smith, 2011). However, both these systems can stimulate discussions and debates, when the online polls are closed. Also, they can support interactions between students and content, students and teacher, and among students. The objectives of this investigation were to study whether the use of technology influenced students' views on a collaborative problem-based learning environment supporting research-teaching nexus activities and whether student perceptions about their research skills development were influenced by the use of technology.

\section{Methodology}

\subsection{Experimental Conditions and Participants}

The same teacher delivered two approaches and the teaching took place in a small-scale learning environment (20 students per class) to cover the needs of the independent samples t-test analysis. The learning activities were designed to support the first three descriptors of the research-teaching nexus framework (research-lead, research-tutored and research-oriented).

Forty first-year Psychology students participated in this study and they were split into two groups. Group A $(\mathrm{N}=20)$ firstly attended the learning approach with technology (Teaching 2) and then the learning approach without technology (Teaching 1), while Group B $(\mathrm{N}=20)$ followed the opposite order. In both teaching approaches the teacher initial started by presenting the theory behind the independent samples t-test and introduced the class to a research problem. However, the research studies/problems were different in both approaches. 32 students (Group A: N = 14, Group B: $\mathrm{N}=18$ ) completed the online questionnaires after their participation in both approaches. The average age of participants was $19.78 \pm 1.93$ and they were predominantly female (91\%).

Table 1 illustrates the structure of the questionnaires. All sections were mirrored in the survey relating to the two approaches. The online questionnaires took approximately 10 minutes each to complete and student participation was anonymous.

\subsection{Teaching Approach without Technology (Teaching 1)}

Students were given the hypothesis and asked to complete a few questions relating to the design (within or between subjects), data level and distribution based on histograms. They were asked to calculate statistics by hand using step-by-step instructions in a workbook and used a critical values table to decide whether or not the result was significant. They were then given an example of how to write up the result in a report.

\subsection{Teaching Approach Using (Game-Based) Student Response Systems}

This initial part of the process was similar with the previous teaching approach and the groups were encouraged to consider the rationale of the study and form an experimental hypothesis. Kahoot allowed groups of students to compete 
against one another while testing their knowledge. The pause between questions gave the teacher a chance to discuss the correct answer with the class and to provide formative feedback (Figure 1).

Table 1. Structure of the online survey ${ }^{\mathrm{a}}$.

\begin{tabular}{|c|c|c|}
\hline \multirow{2}{*}{ Sections } & \multicolumn{2}{|c|}{ Title and short description } \\
\hline & Title & Description \\
\hline Section A & Personal Information & $\begin{array}{l}\text { It included items relating to gender, } \\
\text { age and previous subject experience. }\end{array}$ \\
\hline Section B & $\begin{array}{l}\text { Research-Teaching } \\
\text { Nexus Descriptors }\end{array}$ & $\begin{array}{l}\text { It included items relating to the extent } \\
\text { to which teaching was research-led, } \\
\text { research-orientated, research-tutored. }\end{array}$ \\
\hline Section C & $\begin{array}{l}\text { Research Methods and } \\
\text { Statistics Skills Development }\end{array}$ & $\begin{array}{l}\text { It included items relating to } \\
\text { research methods and statistics } \\
\text { skills development. }\end{array}$ \\
\hline
\end{tabular}

a. The quantitative scales for each item in section $\mathrm{B}$ and $\mathrm{C}$ was from 0 to 10 points.

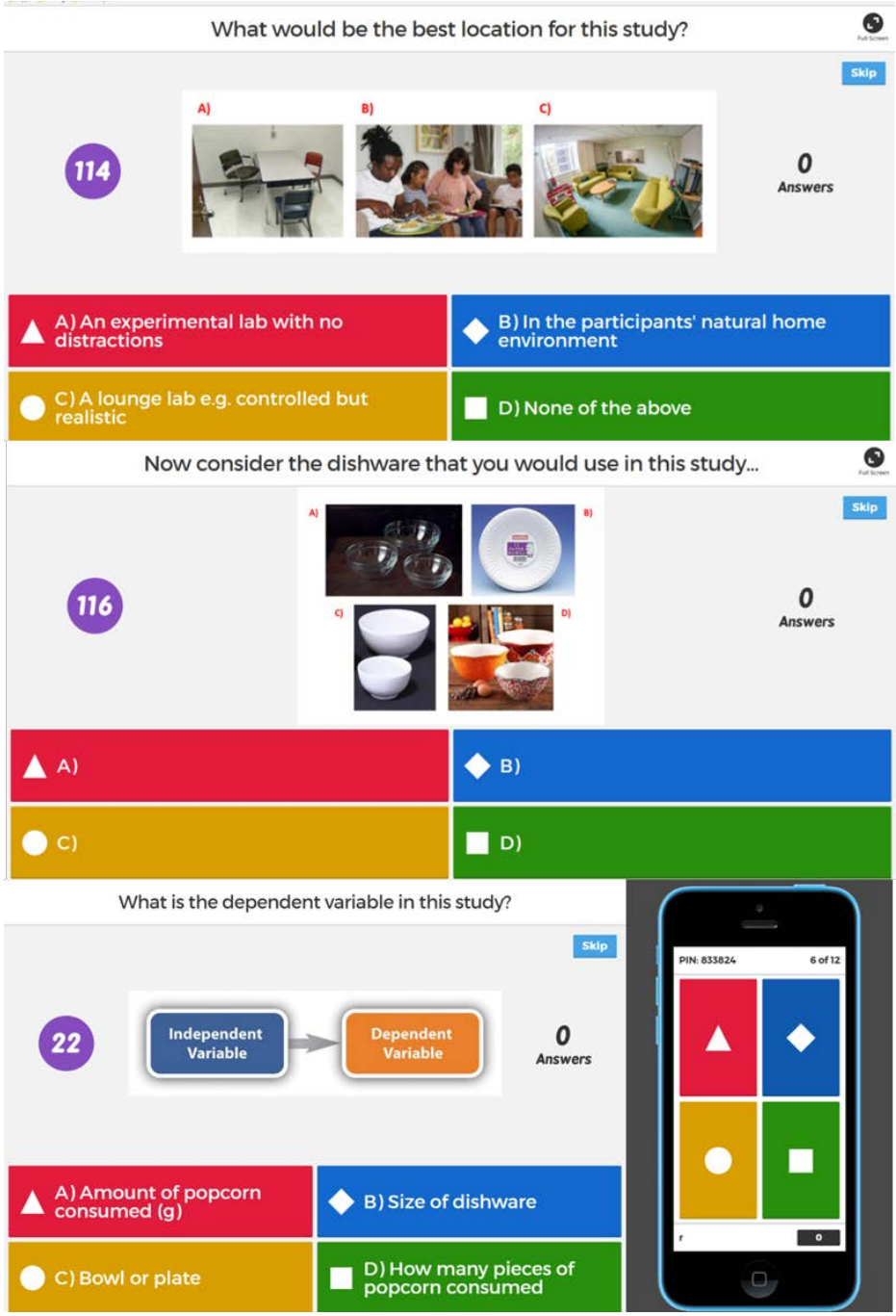

Figure 1. Screen shots from the Kahoot game. 
Following the Kahoot game students were given an example set of data for the given research question and asked to fill in the blanks for hand calculations. The main focus here was to get students to understand the mathematical underpinnings of the independent samples t-test, the interpretation of the test statistic using a critical values table, being able to report the findings and relate back to the hypothesis. Students were instructed to work together to answers several questions in their workbooks.

In the second half of the teaching session, a different research example was provided to students. For the purpose of this activity, Poll Everywhere gave students the opportunity to individually participate and submit their answer to questions relating to research design, hypotheses, data handling and data interpretation (Figure 2). Different types of questions, such as multiple-choice questions and clickable images, allowed students to response independently and anonymously.

\section{Results}

Questionnaire items were organized into themes relating to the research-teaching nexus, research methods and statistics skills development, and were included in three separate repeated measures MANOVAs. Approach (Teaching 1/Teaching 2) and items were included as within subject variables and class (Group A/Group B) as the between subject variable to test for any effect of class order. Initially, the first-year students expressed their views related to their expectations and preparedness for a "Research methods and statistics" module along with their statistics anxiety and their difficulties experienced on these modules. The majority $(84 \%)$ did not have math or statistics experience. The extent to which students worried about research methods and statistics modules was extremely varied, with a mean score of $5.09( \pm 2.43)(0=$ not worried at all, $10=$ extremely worried).

Table 2 shows the mean $( \pm \mathrm{SD})$ for the Teaching 1 and 2 approaches on items relating to the extent to which approaches were informed by the research interests of School staff (Q1), research-led (Q2), research-oriented (Q3) and research-tutored (Q4) activities and the extent to which the approaches were teacher vs. student centered (Q5). The definitions of research-led, research-oriented and research-tutored teaching along with student-centered approach were provided to students before being asked to complete the questionnaire. A repeated measures MANOVA revealed that there was a main effect of approach on items relating to the research-teaching nexus $\mathrm{F}(1,30)=89.38, p<.001, \eta p .2=.75$, such that the Teaching 2 approach $(7.58 \pm 1.52)$ was perceived to better satisfy the research-teaching nexus when compared to the Teaching 1 approach $(4.38 \pm 1.45)$. Participants' mean response scores where significantly higher for the Teaching 2 approach on all items relating to the research-teaching nexus $(p<.001)$, thus, there was no significant item by approach interaction $\mathrm{F}(4,120)=.90, p=.466$, $\eta$ p. $2=.03$. Furthermore, there was no approach by class interaction $\mathrm{F}(1,30)$ $=.01, p=.911, \eta p .2=.00$, indicating that the effect of approach was not depen- 
dent on the class order.

Additionally, students reported a reduced division between staff and students, when technology was used and they improved knowledge of departmental research. Divisions between peers were also reported to be reduced by use of technology, furthermore, $78 \%$ of students reported that they enjoyed the competitive nature of the teaching 2 activities $(\geq 6$, when $0=$ not at all, $10=$ very enjoyable). Table 3 shows the mean $( \pm S D)$ for the two teaching approaches on items relating to research methods and statistics skills development.

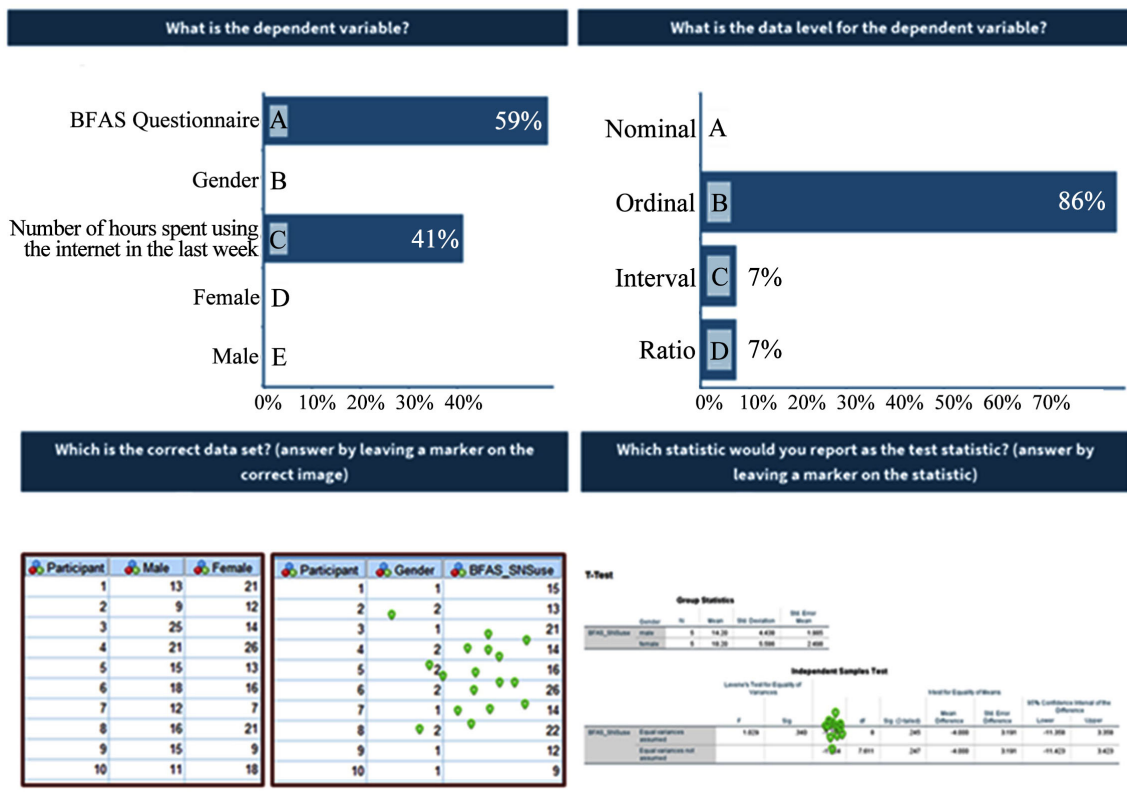

Figure 2. Example screenshots from PollEveryWhere.

Table 2. Means $( \pm \mathrm{SD})$ for the two teaching approaches (1 and 2$)$ on items relating to the research-teaching nexus activities.

\begin{tabular}{|c|c|c|c|}
\hline \multirow[b]{2}{*}{ Question $^{\mathrm{a}}$} & \multicolumn{3}{|c|}{ Title and short description } \\
\hline & $\begin{array}{l}\text { Statement: To what extent students } \\
\text { thought that }\end{array}$ & Teaching 1 & Teaching 2 \\
\hline Q1 & $\begin{array}{l}\text { Activities were informed by research } \\
\text { interests of School staff }\end{array}$ & $3.84( \pm 1.80)$ & $7.38( \pm 2.09)$ \\
\hline Q2 & $\begin{array}{l}\text { This was a research-led teaching ap- } \\
\text { proach }\end{array}$ & $4.38( \pm 2.28)$ & $7.47( \pm 2.14)$ \\
\hline Q3 & $\begin{array}{c}\text { This was a research-oriented teaching } \\
\text { approach }\end{array}$ & $5.03( \pm 2.04)$ & $7.75( \pm 1.72)$ \\
\hline Q4 & $\begin{array}{l}\text { This was a research-tutored teaching } \\
\text { approach }\end{array}$ & $4.38( \pm 2.11)$ & $7.88( \pm 1.60)$ \\
\hline Q5 & This was a student-centered approach & $4.28( \pm 2.52)$ & $7.44( \pm 1.87)$ \\
\hline
\end{tabular}

a. Q1. $(0=$ no effort made to use staff research interests to inform learning and teaching activities, $10=$ all learning and teaching activities are informed by the research interests of staff in the school), Q2. $(0=$ not at all, $10=$ fully integrate research-led approach), Q3. $(0=$ not at all, $10=$ fully integrate research-orientated approach $)$, Q4. $(0=$ not at all, $10=$ fully integrate research-tutored $), Q 5 .(0=$ teacher-centered, $10=$ student-centered). 
Table 3. Means ( \pm SD) for the two teaching approaches (1 and 2 ) on items relating to research methods and statistics skills development.

\begin{tabular}{|c|c|c|c|}
\hline \multirow[b]{2}{*}{ Question $^{\mathrm{a}}$} & \multicolumn{3}{|c|}{ Title and short description } \\
\hline & $\begin{array}{l}\text { Statement: To what extent } \\
\text { students thought that they } \\
\text { developed the following skills }\end{array}$ & Teaching 1 & Teaching 2 \\
\hline Q6.1 & $\begin{array}{l}\text { Formulating a rationale for a research } \\
\text { project based on previous literature }\end{array}$ & $4.28( \pm 1.94)$ & $7.41( \pm 1.90)$ \\
\hline Q6.2 & $\begin{array}{l}\text { Formulating a research hypothesis based } \\
\text { on a specific research topic }\end{array}$ & $5.38( \pm 2.32)$ & $7.66( \pm 1.95)$ \\
\hline Q6.3 & $\begin{array}{l}\text { Research design and considerations of } \\
\text { independent variables and dependent } \\
\text { variables }\end{array}$ & $6.50( \pm 2.20)$ & $8.50( \pm 1.30)$ \\
\hline Q6.4 & $\begin{array}{c}\text { Practical research skills i.e. organising } \\
\text { experimental tasks, conditions, } \\
\text { measuring etc. }\end{array}$ & $6.03( \pm 2.27)$ & $8.22( \pm 1.54)$ \\
\hline Q6.5 & $\begin{array}{l}\text { Data handling, e.g. inputting data, } \\
\text { labelling data, missing values, } \\
\text { recoding etc. }\end{array}$ & $7.31( \pm 2.36)$ & $7.22( \pm 2.25)$ \\
\hline Q6.6 & $\begin{array}{l}\text { Assessing distribution and checking } \\
\text { assumptions }\end{array}$ & $8.03( \pm 1.49)$ & $7.66( \pm 1.75)$ \\
\hline Q6.7 & Running statistical analysis by hand & $8.19( \pm 2.12)$ & $6.41( \pm 2.95)$ \\
\hline Q6.8 & Interpreting results/output & $7.03( \pm 2.02)$ & $8.03( \pm 1.60)$ \\
\hline Q6.9 & Reporting statistics & $7.78( \pm 1.70)$ & $8.31( \pm 1.42)$ \\
\hline Q6.10 & Relating back to the hypothesis & $6.59( \pm 1.79)$ & $8.06( \pm 1.54)$ \\
\hline Q6.11 & Critically reflecting on research findings & $4.41( \pm 2.41)$ & $6.97( \pm 1.64)$ \\
\hline
\end{tabular}

a. $0=$ do not develop at all, $10=$ well-developed.

A repeated measures MANOVA revealed that there was a significant main effect of approach on skills development $\mathrm{F}(1,30)=18.50, p<.001, \eta p .2=.38$, such that the Teaching 2 approach $(7.68 \pm 1.18)$ was perceived to develop research methods and statistics skills significantly better than the Teaching 1 approach $(6.50 \pm 1.38)$. There was a significant item by approach interaction $\mathrm{F}(5$, $153)=15.93, p<.001, \eta p .2=.35$, caused by significantly better perceived development of skills by the Teaching 2 approach relating to formulating a rationale and hypothesis $(p<.001)$, research design and practical research skills ( $p$ $<.001)$, interpreting results/output $(p=.012)$, relating back to the hypothesis and critical reflection on research findings $(p<.001)$. However, students perceived the Teaching 1 approach to develop statistics by hand skills significantly better than the Teaching 2 approach $(p=.009)$ and there was no significant difference between approaches for skills relating to data handling, assessing distribution/assumptions and reporting statistics $(p>.05)$. Finally, there was no significant approach by class interaction $\mathrm{F}(1,30)=.10, p=.750, \eta \mathrm{p} .2=.00$, indicating that the effect of approach was not dependent on the class order. 


\section{Discussion}

The aim of this investigation was to give students the opportunity to express their views on the two different teaching approaches under the perspectives of the research-teaching nexus activities and student skill development. In both cases, the classes were taught by the same teacher in the same teaching room and the study scenarios were based on real research projects. All participants followed both teaching approaches. A counterbalance was used to control for previous experience of the statistical test using technology and no class order by approach interaction was found. The questionnaire was not focused directly on student satisfaction, as according to Davies et al. (2013) factors that play important role in a creative learning environment are the relationship between students and teachers, the enjoyable atmosphere of environment and the skills development. The research-teaching nexus framework supports activities which promote learning and skills development process through discussion, problem-based and teacher-student interactions. However, the use of technology played a significant role for creating an enjoyable learning environment for students. The choice of Web 2.0 applications mainly made because of discussion promotions in class, the easiness of use and entertainment that might offer (competition between students).

Overall, students perceived the use of (game-based) student response systems better satisfy the research-teaching nexus learning activities allowed them to develop research skills. Specifically, students perceived the Teaching 2 approach to be more research-led and better informed by departmental research. Also, it was perceived to be more research-oriented including activities relating to all stages of the research process, and the problem-based activities encouraged students to work in research and inquiry mode. Students' enjoyed the problem-based approach through the use of (game-based) student response systems making research decisions such as hypothesizing and designing the study. Finally, students found the integration of a research-tutored approach and felt that the Teaching 2 approach was significantly more student-led than the one without the use of technology. Students felt that the Teaching 2 approach reduced the division between staff and students due to the use of technology and research-led study scenarios helped them to engage with research being conducted in the School. The Teaching 2 approach therefore increases the interaction between students, students and staff, and students and content.

The majority of the Universities spend time in their curriculum on research skills development. It seems that students better develop research methods and statistics skills, specifically, formulating a rationale and hypothesis, research design and practical research skills, interpreting results/output, relating back to the hypothesis and critical reflection on research findings, if the Web 2.0 applications were integrated into the learning process. Many researchers have advocated that the barrier of their stress and math anxiety along with the level of their preparedness for a research methods and statistics module prevented them 
for actively participate in learning (Mulhern \& Wylie, 2004; Tishkovskaya \& Lancaster, 2012; Wilson, 2013; Boyle et al., 2014). However, the integration of technology allowed students to think around research projects in a more enjoyable way and to overcome the math "fear".

The Teaching 2 approach was not perceived to significantly better develop data handling, assessing distribution/assumptions and reporting statistics, as it incorporated some basic elements of data handling by asking students to choose images of appropriate data sets. However, this part could be improved in the future by incorporate more advanced learning tasks/problems. Similar to previous research (Ball \& Pelco, 2006; Elder, 2015) the current study did not analyze exam performance, but this is an action which will be considered in the future. Although this approach was designed to support a psychology curriculum, the main aspects of the interactive blended learning approach, such as problem-solving, collaboration and (game-based) student response systems, can support the curriculum of other disciplines which include research methods and statistics (or relevant) modules in order to enhance their research-teaching nexus activities. The aim of the technology integration into a research methods and statistics module should be the support of a creative learning environment. This could prevent students' negative attitudes towards statistics and encourage them to see the real-life application of these skills.

\section{Acknowledgements}

The authors received no financial support for the research and authorship of this article.

\section{Conflicts of Interest}

The authors declare no conflicts of interest regarding the publication of this paper.

\section{References}

Aditomo, A., Goodyear, P., Bliuc, A. M., \& Ellis, R. A. (2011). Inquiry-Based Learning in Higher Education: Principal Forms, Educational Objectives, and Disciplinary Variations. Studies in Higher Education, 38, 1239-1258.

https://doi.org/10.1080/03075079.2011.616584

Al-Maktoumi, A., Al-Ismaily, S., \& Kacimov, A. (2016). Research-Based Learning for Undergraduate Students in Soil and Water Sciences: A Case Study of Hydropedology in an Arid-Zone Environment. Journal of Geography in Higher Education, 40, 321-339. https://doi.org/10.1080/03098265.2016.1140130

Ball, C. T., \& Pelco, L. E. (2006). Teaching Research Methods to Undergraduate Psychology Students Using an Active Cooperative Learning Approach. International Journal of Teaching and Learning in Higher Education, 17, 147-154.

Boyle, E. A., MacArthur, E. W., Connolly, T. M., Hainey, T., Manea, M., Kärki, A., \& Van Rosmalen, P. (2014). A Narrative Literature Review of Games, Animations and Simulations to Teach Research Methods and Statistics. Computers \& Education, 74, 1-14. https://doi.org/10.1016/j.compedu.2014.01.004 
Buckley, C. A. (2011). Student and Staff Perceptions of the Research-Teaching Nexus. Innovations in Education and Teaching International, 48, 313-322. https://doi.org/10.1080/14703297.2011.593707

Davies, D., Jindal-Snape, D., Collier, C., Digby, R., Hay, P., \& Howe, A. (2013). Creative Learning Environments in Education-A Systematic Literature Review. Thinking Skills and Creativity, 8, 80-91. https://doi.org/10.1016/j.tsc.2012.07.004

Elder, A. D. (2015). Using a Brief Form of Problem-Based Learning in a Research Methods Class: Perspectives of Instructor and Students. Journal of University Teaching and Learning Practice, 12, 8.

Firsing, S. L., Yannessa, J. F., McGough, F. A. D., Delport, J., Po, M. C., \& Brown, K. (2017). Millennial Student Preference of Audience Response System Technology. Pedagogy in Health Promotion, 4, 4-9. https://doi.org/10.1177/2373379917698163

Gardner, A., \& Willey, K. (2018). Academic Identity Reconstruction: The Transition of Engineering Academics to Engineering Education Researchers. Studies in Higher Education, 43, 234-250. https://doi.org/10.1080/03075079.2016.1162779

Griffiths, R. (2004). Knowledge Production and the Research-Teaching Nexus: The Case of the Built Environment Disciplines. Studies in Higher Education, 29, 709-726. https://doi.org/10.1080/0307507042000287212

Hajdarpasic, A., Brew, A., \& Popenici, S. (2015). The Contribution of Academics' Engagement in Research to Undergraduate Education. Studies in Higher Education, 40, 644-657. https://doi.org/10.1080/03075079.2013.842215

Healey, M. (2005). Linking Research and Teaching: Disciplinary Spaces. In R. Barnett (Ed.), Reshaping the University: New Relationships between Research, Scholarship and Teaching (pp. 30-42). Maidenhead, UK: Open University Press.

Healey, M., \& Jenkins, A. (2009). Developing Undergraduate Research and Inquiry. Higher Education Academy.

https://www.heacademy.ac.uk/knowledge-hub/developing-undergraduate-research-an d-inquiry

Healey, M., Jordan, F., Pell, B., \& Short, C. (2010). The Research-Teaching Nexus: A Case Study of Students' Awareness, Experiences and Perceptions of Research. Innovations in Education and Teaching International, 47, 235-246. https://doi.org/10.1080/14703291003718968

Karpiak, C. P. (2011). Assessment of Problem-Based Learning in the Undergraduate Statistics Course. Teaching of Psychology, 38, 251-254. https://doi.org/10.1177/0098628311421322

Kirschner, P. A., Sweller, J., \& Clark, R. E. (2006). Why Minimal Guidance during Instruction Does Not Work: An Analysis of the Failure of Constructivist, Discovery, Problem-Based, Experiential, and Inquiry-Based Teaching. Educational Psychologist, 41, 75-86. https://doi.org/10.1207/s15326985ep4102_1

Levy, P., \& Pertulis, R. (2012). How Do First-Year University Students Experience Inquiry and Research, and What Are the Implications for the Practice of Inquiry-Based Learning? Studies in Higher Education, 37, 85-101.

Mackeski, G., Buhrmann, J., \& Lowney, K. S. (2008). Overcoming Student Disengagement and Anxiety in Theory, Methods and Statistics Course by Building a Community of Learners. Teaching Sociology, 36, 42-48. https://doi.org/10.1177/0092055X0803600106

Mulhern, G., \& Wylie, J. (2004). Changing Levels of Numeracy and Other Core Mathematical Skills among Psychology Undergraduates between 1992 and 2002. British Journal of Psychology, 95, 355-370. https://doi.org/10.1348/0007126041528176 
Plump, C. M., \& LaRosa, J. (2017). Using Kahoot! In the Classroom to Create Engagement and Active Learning: A Game-Based Technology Solution for eLearning Novices. Management Teaching Review, 2, 151-158. https://doi.org/10.1177/2379298116689783

Ramirez, C., Schau, C., \& Emmioglu, E. (2012). The Importance of Attitudes in Statistics Education. Statistics Education Research Journal, 11, 57-71.

Rice, J. W. (2012). The Gamification of Learning and Instruction: Game-Based Methods and Strategies for Training and Education. International Journal of Gaming and Computer-Mediated Simulation, 4, 81-83. https://doi.org/10.4018/jgcms.2012100106

Robertson, J., \& Blackler, G. (2006). Students' Experiences of Learning in a Research Environment. Higher Education Research \& Development, 25, 215-229. https://doi.org/10.1080/07294360600792889

Roblyer, M. (2016). Integrating Educational Technology into Teaching (7th ed.). Boston, MA: Pearson.

Shon, H., \& Smith, L. (2011). A Review of Poll Everywhere Audience Response System. Journal of Technology in Human Services, 29, 236-245.

https://doi.org/10.1080/15228835.2011.616475

Stappenbelt, B. (2013). The Effectiveness of the Teaching-Research Nexus in Facilitating Student Learning. Engineering Education, 8, 111-121. https://doi.org/10.11120/ened.2013.00002

Stowell, J. R. (2014). Use of Clickers vs. Mobile Devices for Classroom. Computers and Education, 82, 329-334. https://doi.org/10.1016/j.compedu.2014.12.008

Tishkovskaya, S., \& Lancaster, G. A. (2012). Statistical Education in the 21st Century: A Review of Challenges, Teaching Innovations and Strategies for Reform. Journal of Statistics Education, 20, 1-24. https://doi.org/10.1080/10691898.2012.11889641

Walkington, H. (2015). Students as Researchers: Supporting Undergraduate Research in the Discipline in Higher Education. Higher Education Academy.

https://www.heacademy.ac.uk/system/files/resources/Students\%20as\%20researchers_1. pdf

Wang, A. I. (2015). The Wear out Effect of a Game-Based Student Response System. Computers \& Education, 82, 217-227. https://doi.org/10.1016/j.compedu.2014.11.004

Wiggins, S., Chiriac, E. H., Abbad, G. L., Pauli, R., \& Worrell, M. (2016). Ask Not Only "What Can Problem-Based Learning Do for Psychology?" But "What Can Psychology Do for Problem-Based Learning?" A Review of the Relevance of Problem-Based Learning for Psychology Teaching and Research. Psychology Learning \& Teaching, 15, 136-154. https://doi.org/10.1177/1475725716643270

Wilson, S. G. (2013). The Flipped Class: A Method to Address the Challenges of an Undergraduate Statistics Course. Teaching of Psychology, 40, 193-199.

https://doi.org/10.1177/0098628313487461 